\title{
THE USE OF CONTRACTED FORMS OF ALBANIAN LANGUAGE \\ IN ELECTRONIC MEDIA TEXTS
}

\section{Prof. Asoc. Dr. Flamur SHALA id 1* \\ Prof. Ass. Dr. Xhafer BEQIRAJ (iD 2}

1 University “Ukshin Hoti” Prizren, Faculty of Philology, flamur.shala@uni-prizren.com *Correspondent Author.

2 University “Ukshin Hoti” Prizren, Faculty of Philology, xhafer.beqiraj@uni-prizren.com

\begin{abstract}
Article history:
Submission 19 August 2020

Revision 28 September 2020

Revision 02 November 2020

Accepted 25 November 2020

Available online 31 December 2020

\section{Keywords:}

Contracted Forms,

Misuse of The Contracted Forms,

Written Media,

Correct Use

Connected Contracted Forms.

A b s t r a c t

The contracted forms of literary Albanian are of dative case of all person's singular and plural and of the accusative case in the third person singular and plural. In certain syntactic constructions they merge and thus form connected contracted forms. When used near each other, the first is dative, while the second is accusative. Their use according to the norm are correct. Their topic in the sentence is arranged and a linguist or a lecturer should not miss the omissions in texts with short, separate, or connected forms. On the contrary, we encounter misuses of short forms of Albanian in texts of published and electronic media. They are incorrectly used in some syntactic constructions, marked by case in case, one by one. Contracted form locations and their referral to a different pronoun or name as a repetition of an object appear to be harmonized with the respective forms as an object or its repetition. They are placed in front of the verb forms of each tense. Except in imperative they have a double topic. The contracted forms during usage in the dative and accusative cases directly mark direct or indirect object. The contracted forms of the first and second person singular and plural, in the dative case, are often used to mark directly the indirect object. The misuse of the contracted forms is more common in the third person of the dative case when i.e. singular (i) is used instead of plural (u). We also encounter the incorrect use of the contracted forms of the second person plural of the dative case (juve) you instead of (atyre $u$ ). This research reveals the wrong use of contracted

forms in the texts of some electronic media (portals) in Pristina and Tirana.
\end{abstract}

\section{Introduction}

The contracted forms of literary Albanian are of dative case of all person's singular and plural and of the accusative case in the third person singular and plural (Agalliu, F., Angoni E., Demiraj, Sh., Dhrimo, A., Hysa, E., Lafe, E., Likaj, E. 2002). In certain syntactic constructions they merge and thus form connected contracted forms. When used near each other, the first is dative, while the second is accusative. The connected contracted forms we encounter even in the cases of joining the dative case ( $i, u)$, and the particle of the subjunctive, future tense, infinitive or participle, i.e. t'i bëhen, t'u bëhen dhe t'ju them, për t'i bërë, për t'u bërë, t'ia thuash; do t'ia tregoja; do ta njoftoj; për t'ia dalë në krye; me t'ia treguar; etj." (Kostallari, A., Domi, M., Çabej, E., Lafe, E., 1973).
These connected contracted forms are also present in the cases of joining the form of dative (ty të) and the particle (u) of the past simple of passive voice u (u duk), i.e.: "nuk m'a dha; m'u bë zemra mal; në m'u dhëntë rasti etj.; si t'u duk ; mos t'u ndaftë e mira!; t'u bëftë pushka top!" etj.” (Kostallari, A., Domi, M., Çabej, E., Lafe, E., 1973).

They are placed in front of the verb forms of each tense. Their topic in the sentence is arranged and a linguist or a lecturer should not miss the omissions in texts with short, separate, or connected forms. Their use according to the norm is no doubt correct.

On the contrary, we encounter misuses of short forms of Albanian in texts of published and electronic media. They are incorrectly 
used in some syntactic constructions, marked by case in case, one by one.

Contracted form locations and their referral to a different pronoun or name as a repetition of an object appear to be harmonized with the respective forms as an object or its repetition. They are placed in front of the verb forms of each tense. Except in imperative they have a double topic (Agalliu, F., Angoni E., Demiraj, Sh., Dhrimo, A., Hysa, E., Lafe, E., Likaj, E.2002).

Placing before or after a verb, as an inseparable part of it, has made the short forms to be treated as "pre-placed, afterplaced, sub-placed agglutinative elements" ... and "brought to the verb almost as so-called prefixes" (Pernaska 2012). Although they are no longer personal pronouns, they have retained their person marking ability. By preserving this ability, they preserve the person of the object and play the role of "verbal clauses" (Përnaska 2012). Short forms retain this ability and mark the object's person for each case, as the datum (mua më, ty të, atijasaj $i$, neve na, juve ju, aryre $u$ ) in all the singular and plural ones, as well as the accusative case in the third singular person (that 'e') and the plural (ata-ato i).

The merging of the short forms and the datum, for each person of personal pronoun, with the short form of the singular and plural third person of the accusative case (Agalliu, F., Angoni E., Demiraj, Sh., Dhrimo, A., Hysa, E., Lafe, E., Likaj, E., 2002), is done based on their own preservation (the singular of the datum and the singular of the accusative: $m \ddot{e}+e=m a ; t y+e=t a ; i+e=i a$, the plural of datum and the singular of the accusative: na+e=na e; $j u+e=j u a ; u+e=u a$, and the singular of datum and the plural of the accusative: $m e ̈+i=m$ 'i; të $+i=t^{\prime} i ; i+i=i a ;$ plural of datum and plural of the accusative: $n a+i=n a i ; j u+i=j u a ; u+i=u a)$.

The contracted forms during usage in the dative and accusative cases directly mark direct or indirect object. The contracted forms of the first and second person singular and plural, in the dative case, are often used to mark directly the indirect object (Agalliu, F., Angoni E., Demiraj, Sh., Dhrimo, A., Hysa, E., Lafe, E., Likaj, E.2002).

This research reveals the wrong use of contracted forms in the texts of some electronic media (portals) in Pristina and Tirana.

As it is said, the short (contracted) formations of the Albanian language are in most cases a repetition of the direct and indirect object, and they are also a union of two cases, of the dative in all persons and of the accusative in the third person. Using them incorrectly in the texts of some portals induces the curiosity of handling these uses. Their avoidance is not essentially spelling or purely morphological, they are also syntactic. We will extract the examples, extracted from the texts, to make the analysis more interesting.

\section{Materials and Methods}

In the texts of some electronic media in Pristina and Tirana we have occasionally encountered some misuses of some short forms of pronouns. These forms have been found in certain syntactic constructs, identified in texts of a lot of portals or Albanian newspapers, as in: Zëri.info, Gazeta: EXPRESS, Indeksonline, koha.net, Telegrafi.com, Bota sot, Botapress, gazeta Shekulli, gazeta Tema, Panorama online, etc.

The curiosity to research about these uses was spurred more by the repetition of the same uses of short (contracted) forms in the above-mentioned electronic media texts. The most incorrectly used short (contracted) forms that we encounter are: the form ju (juve ju) instead of u, i.e. ...atyre më pas ju bëhej e qartë.... (Gazeta Tema, 5.09.2018.), form i instead of $u$, i.e. ...kjo $i$ (duhet, u ndodh, v.j.) ndodh kosovarëve që e mashtrojnë Zvicrën...(GAZETA: EXPRESS 31.10.2017); Me këtë mendim dhe qëndrim i rikthehet (duhet, $u$ rikthehet, v.j.) shteteve në linja etnike... (GAZETAEXPRESS 31 oktober 2017); connected form $t$ ' $i$ instead of t'u, i.e. Para se të jetonte në fshehtësi për t'i shpëtuar (duhet, t'u shpëtuar, v.j.) internimeve të hebrenjve (Indeksonline 21.09.2018); connected form $i u$ instead of $u$, Mbyllja qё iu (duhet u është bërë, v.j.) është bërë dhjetëra institucioneve arsimore në mbarë vendin (Gazeta Shekulli 5.09.2018); connected form ia instead of $u a$, i.e. Një qeveri që shkurton buxhetin e arsimit dhe ia shpërndan atë kriminelëve (Gazeta Shekulli 5.09.2018); unnecessary form e, i.e. Shqipëria socialiste e arriti përsëri lumturinë: gjithcka falas...,(Gazeta Shekulli 5.09.2018); the lack of short form i or e in certain formations, p.sh. "N $\ddot{e}$ vitin 2017, autoritetet e Kosovës arrestuan 5 individë të tjerë nën të njëjtat akuza (Panorama, Sep 19, 2018); ia instead of $i$, (i arrestuan 5 individë...) stylistically likable, p.sh. Heshtur apo hapur atij ia kanë dhënë mandatin për të negociuar......" (Zëri.info 25 August 2018); It should be, $i$ kanë dhënë mandatin për të negociuar, without the forms e of accusative, connected with the $\mathrm{i}$ of the dative in $i a$.

\section{Results}

The contracted forms of literary Albanian are of dative case of all persons singular and plural and of the accusative case in the third person singular and plural. When used near each other, the first is dative, while the second is accusative. The connected contracted forms are encountered in cases of joining the dative $i$, $u$, and particle të subjunctive, of the future tense, infinitive and participle, i.e: t'i bëhen, t'u bëhen dhe t'ju them, për t'i bërë, për t'u bërë, t'ia thuash; do t'ia tregoja; do ta njoftoj etj." These connected contracted forms are also present in the cases of joining 
the form of dative (ty të) and the particle (u) of the past simple of passive voice u (u duk), i.e.: "nuk m'a dha; m'u bë zemra mal; në m'u dhëntë rasti etj.; si t'u duk; mos t'u ndaftë e mira!; t'u bëftë pushka top!" etc.

They are placed in front of the verb forms of each tense. Their topic in the sentence is arranged and a linguist or a lecturer should not miss the omissions in texts with short, separate, or connected forms. On the contrary, we encounter misuses of short forms of Albanian in texts of published and electronic media. This research expounds the misuse of connected short forms found in the texts of some electronic media in Pristina and Tirana. These forms have been found in certain syntactic constructs, identified in texts of a lot of portals or Albanian newspapers, as in: Zëri.info, gazeta EXPRESS, Indeksonline, koha.net, Telegrafi.com, Bota sot, Botapress, gazeta Shekulli, gazeta Tema, Panorama online, etc. The curiosity to research about these uses was spurred more by the repetition of the same uses of short (contracted) forms in the above-mentioned electronic media texts. The most incorrectly used short (contracted) forms that we encounter are: the form ju (juve ju) instead of $u$, i.e. ...atyre më pas ju bëhej e qartë...., form $\mathrm{i}$ instead of $u$, i.e. ....kjo $i$ (duhet $u$ ndodh, v.j.) ndodh kosovarëve qё e mashtrojnë Zvicrën...; Me këtë mendim dhe qëndrim $i$ rikthehet (duhet $u$ rikthehet, v.j.) shteteve në linja etnike...; connected form t'i instead of $t^{\prime} u$, i.e. Para se të jetonte në fshehtësi për t'i shpëtuar (duhet për t'u shpëtuar, v.j.) internimeve të hebrenjve.; connected form iu instead of $u$, Mbyllja që iu (duhet u është bërë, v.j.) është bërë dhjetëra institucioneve arsimore në mbarë vendin.; connected form ia instead of ua, i.e. Një qeveri qü shkurton buxhetin e arsimit dhe ia shpërndan atë kriminelëve.; unnecessary form e, i.e. Shqipëria socialiste e arriti përsëri lumturinë: gjithcka falas..., the lack of short form i or e in certain formations, p.sh. "Në vitin 2017, autoritetet e Kosovës arrestuan 5 individë të tjerë nën të njëjtat akuza. ia instead of i, (i arrestuan 5 individë...) stylistically likable, p.sh. Heshtur apo hapur atij ia kanë dhënё mandatin për të negociuar .......”. It should be, $i$ kanë dhënë mandatin për të negociuar, without the forms e of accusative, connected with the $i$ of the dative in ia.

\section{Discussion of Findings}

It is common to wrongly use the contracted forms, as in the third person of dative case, when the singular of the (i) (atyre i) form is used instead of the plural $u$ (atyre $u$ ). Also, the incorrect use of the contracted form of the second-person plural of the dative case ju (juve ju) instead of (atyre u) is often encountered. For misuse of short texts we often find in the texts of Albanian portals, in prestigious newspapers like the newspaper Tema, i.e. “...pasi njoftoheshin për pozicionin e punës atyre më pas ju (në vend të u bëhej) bëhej e qartë puna që duhet të bënin. In the Telegrafi.com, i.e. E gjithë kjo bëhet në kuadër të platformës "Të rëndësishëm janë njerëzit”, me të cilën njerëzve ju jepet rëndësi më shumë (Gazeta Tema, 5.09.2018). As we mentioned above, in these sentences the contracted form ju second person plural of the dative case instead of $\mathrm{u}$ third person dative (It should be: atyre më pas $u$ bëhej..., dhe njerëzve u jepet rëndësi...).

There are frequent misused of the contracted forms such as singular dative, which is used instead of plural dative. At least a few daily electronic newspapers encounter these uses, the frequency of which makes us believe that such misuses are more than an avoidance. For example: Kjo $i$ ndodh kosovarëve që $e$ mashtrojnë Zvicrën (GAZETAEXPRESS 31 oktober 2017). Instead of se Kjo u ndodh kosovarëve që e mashtronjë Zvicrën; Ai ka shprehur mirënjohje për administratën e Donald Trump rreth mbështetjes qё po $i$ bën negociatave Kosovë-Serbi, të ndërmjetësuara nga Bashkimi Evropian (Koha net, 20 shtator 2018), në vend se ...për administratën e Donald Trump rreth mbështetjes qё po u bën negociatave Kosovë-Serbi...

In another use, in a line with the example above, we do not only make use of the wrong short form, but also the verb bashkohen instead of bashkohet, extract from the context. i.e. Ai ka bërë me dije se LDK në të ardhmen..... Thotë se edhe protestave të tjera të $V V$ 'së mund t'i bashkohen (GAZETAEXPRESS 18 september 2018), në vend se të shkruhet: protestave të tjera të VV'së mund t'u bashkohet, $L D K$.

We also have cases when the short form t'i joins the form i të-së (Likaj 2015, p. 30, 31). Of the subjunctive and i of dative (asaj i, protestës $i, v . j$.), where $i$ is used instead of $u$ (atyre $u$, protestave u). When it comes to singular nouns like LDK (bashkohet v.j.) and the noun in plural protestave, it should be "Thotë se edhe protestave të tjera të VV'së mund t'u bashkohet (LDK, v.j.)" (Likaj 2015, p. 30, 31). Also in the next sentence t'u (Sulejmani 1984 , p. 72, 73.) is used instead of t'i, i.e....në Amsterdam, para se të jetonte në fshehtësi për t'i shpëtuar (t'u shpëtuar v.j.) internimeve të hebrenjve në kampet famëkeqe naziste në Evropën Lindore (Indeksonline 21.09.2018).

Another use that we often encounter in electronic printed media is the misuse of short connected form iu, i.e. Deputetja ... tha se braktisja masive e shkollave nga plot 133 mijë nxënës dhe mbyllja qё iu është bërë dhjetëra institucioneve arsimore në mbarë vendin, është një rezultat shkatërrimtar... (Gazeta Shekulli 5.09.2018).

In the above mentioned sentence, the use of the form iu (...iu është bërë dhjetëra institucioneve) is wrong because the short form $\mathrm{u}$ is a repetition of the indirect object expressed by atyre $\mathrm{u}$, (Sulejmani 1984, p. 72, 73.), u është bërë dhjetëra institucioneve, 
meanwhile $\mathrm{i}$ is unnecessary and wrong. If we would have the sentence “... mbyllja që $i$ është bërë institucionit, clearly i is short form and repetition of the indirect object atij i (institucionit i). It is known that $\mathrm{i}$ is singular (atij $\mathrm{i}$ është bërë...) and $\mathrm{u}$ is plural (atyre u është bërë).

The form iu reveals that $\mathrm{i}$ - is wrongly used instead of $\mathrm{u}$-, and $\mathrm{u}$ should not be the particle $u$ e of the passive in the past simple. Let us remind that the short form iu is used when dealing with the short form of dative i (asaj, atij i) and the particle $u$ in the passive of past simple, (u bë) si, ,mbyllja qё iu bë institucionit...”, a "mbyllja qё iu bë institucioneve...", when i (atij i) is the short form of dative and $u$ ( $u$ bë) is a particle in the passive of the past tense. Said in other words, the use of the short form iu është bërë is very unnecessary and wrong. It is është bërë in the past simple of the passive makes that the $\mathrm{u}$ (në iu bë) to be $u=\ddot{e} s h t \ddot{e}$, so it is not iu është, but " $и$ është bërë institucioneve.

Another misuse of the connected short forms is ia in particular sentences, i.e. Gjendjen në arsim nuk mund ta ndryshojë një qeveri që shkurton buxhetin e arsimit dhe ia shpërndan atë kriminelëve të lidhur me pushtetin dhe klientëve të....", tha Vokshi ndër të tjera (Sulejmani 1984, p. 72, 73.). It is known that ia refers to the singular of dative case, (ia shpërndan kriminelit, v.j.). Buxhten ia shpërndan kriminelit (jo kriminelëve), should be: “....buxhetin e arsimit ua shpërndan atë kriminelëve.”

In the next example the short form $\mathrm{i}$ of the dative singular is wrongly used instead of u (Demiraj 2015. p. 175, 176.) of dative plural: Ai synon të rikthejë 'Serbinë e madhe” duke përfshirë gjithë pakicat serbe brenda kufijve politikë të shtetit amë, pa marrë parasysh se me këtë mendim dhe qëndrim $i$ rikthehet shteteve në linja etnike, pra në thelb konflikteve dhe luftërave historike (Shekulli 5.09.2018). Ka gjithashtu kritika të forta brenda Kosovës, veçanërisht nga kryeministri..., i cili të premten $i$ referohej diskutimeve si "ide katastrofike" (Gazeta Shekulli 5.09.2018). Ne i kemi premtuar qytetarëve dhe do jemi pranë qytetarëve (Gazeta Tema, 4.09.2018). “...pa marrë parasysh se me këtë mendim dhe qëndrim i rikthehet shteteve në linja etnike" (Zëri.info 04.9.2018).

Another misuse of the short forms id noticed in the below mentioned sentence where ju (veta e dytë, juve ju dhashë (Demiraj 2015. p. 175, 176.) dhe ju ju pashë (Shkurtaj 2006, p. 154.) is used instead of iu (veta e tretë $\mathrm{i}+\mathrm{u}=\mathrm{iu}$ ). It was said earlier the short form $i$ of the dative is joined with $u$ in the passive of past simple (u bë), i.e. Gazetarja Klodiana Lala ka thyer heshtjen dhe ka folur për herë të parë publikisht për sulmin që ju bë asaj 6 ditë mё parë (Gazeta Shekulli 5.09.2018). The wrong use of the short form ju (instead of iu) in also noticed in this example: Ky tipi është akoma gjyqtar dhe atë vit ju shtua pasuria (Gazeta Tema 5.09.2018). So, instead of iu which is a formation of $i+u$ (atij $i$ dhe u shtua, iu shtua) is used ju shtua, i.e. “...dhe të gjithë votuan kundër sepse ashtu ju tha Berisha" (Gazeta Tema 5.09.2018), në vend se të gjithë votuan kundër sepse ashtu iu tha Berisha.

It is to be noticed the wrong use of iu instead of ju in the example: meqenëse jeni ambasador kaq i qetë, për thënien se jeni ndjerë sikur iu kishin goditur me thikë pas shpine (Bota sot, 21 SEPTEMBER 2018). The short form iu (iu tha asaj, nga asaj i dhe $\mathrm{u}$ tha), is different form ju (juve ju kishin goditur). This wrong usage has a controversial side: What are the causes that lead to constant misuse of short forms. I will try to avoid thinking that these are technical, spelling or lecture lacks.

In the cases of the misuse of the short forms of the pronoun: Ne jemi të hapur gjatë gjithë kohës, unë pasi e mora veten nga kjo tronditje, mora vendimin që të reagoja, pasi si gazetare nuk isha e frikësuar (Gazeta Shekulli 5.09.2018), the short form e is repetition of the object atë e, which comes in the phrase e mora veten, a highly used phrase. Stylistically speaking the use of e lowers the stylistic expression that gives the phrase e mora veten (Fjalori i Gjuhës së Sotme Shqipe 1980, p. 1063.).

Even in the sentence: Shqipëria socialiste e arriti përsëri lumturinë: gjithçka falas..., (Gazeta Shekulli 5.09.2018) the short form e (e arriti lumturinë) it is unnecessarily used for two reasons, stylistic and consequently arriti complements the subject than the object lumturinë. Arriti lumturinë is more like a phrase. So with the short form e arriti the verb refers to the word lumturinë because of the repeated object e, ku arriti është qëllimi i kumtimit. In the sentence: "Në vitin 2017, autoritetet e Kosovës arrestuan 5 individë të tjerë nën të njëjtat akuza (Panorama Sep 19, 2018). Is necessary the use of the short form $\mathrm{i}$ (i arrestuan 5 individë), as a repetition of the direct object ( 5 individë i). The repetition of the object is a phenomenon that has evolved with the Albanian language and is characterized as a Balkan language phenomenon (Demiraj 2015. p. 175, 176., 1988. p. 568., Përnaska, 2012. p. 397-398).

In the sentence: "Vetë klasa politike e Kosovës, parlamenti, partitë politike me apo pa vetëdije, heshtur apo hapur atij ia kanë dhënë mandatin për të negociuar me Serbinë pa vija te kuqe, pa limite." (Zëri.info 25 august 2018), the short form ia (atij i, atë $\mathrm{e}=\mathrm{i}+\mathrm{e}=\mathrm{ia}$, ia kanë dhënë mandatin) does not respond completely to the syntactic construction and it is unnecessary the repetition of the short form $\mathrm{i}=\mathrm{e}$ (atë e, mandatin $\mathrm{e}=\mathrm{a}$, atij $i$ kanë dhënë mandatin).

We can encounter the usage of the short for, t'ia in the sentence, votën e tyre për t'ia ndryshuar emrin Maqedonisë shqiptarët 
duhet ta shohin si hapje të një kapitulli të ri (Koha.net 6.09.2018), where të $+\mathrm{i}+\mathrm{e}=\mathrm{t}$ 'ia.

\section{References}

1. Agalliu, F., Angoni E., Demiraj, Sh., Dhrimo, A., Hysa, E., Lafe, E., Likaj, E., (2002). Gramatika e Gjuhës Shqipe 1, Akademia e Shkencave të Shqipërisë, Tiranë.

2. Përnaska, R., (2012). Bashkësia e të ashtuquajturave trajta të shkurtra të përemrave vetorë dhe zgjedhimi nënanor-kundranor (subjektor-objektor) sui generis në gjuhën e sotme shqipe (f.397-410). Shqipja dhe Gjuhët e Ballkanit, Akademia e Shkencave dhe Arteve të Kosovës-Akademia e Shkencave të Shqipërisë, Prishtinë.

3. Demiraj, Sh., (1988). Gramatika historike e gjuhës shqipe, Rilindja, Prishtinë.

4. Demiraj, Sh., (2004). Gjuhësi Ballkanike, Akademia e Shkencave të Shqipërisë, Tiranë.

5. Demiraj, Sh., (2015). Gramatikë historike e gjuhës shqipe, Akademia e Shkencave të Shqipërisë, Tiranë.

6. Dhrimo, A., Angoni, E., Hysa, E., Lafe, E., Likaj, E., Agalliu, F., Demiraj, Sh., (1985). Gramatika e gjuhës së sotme shqipe, Rilindja, Prishtinë.

7. Ethem, L., (2015). Zhvillime të mjeteve gramatikore të shqipes, Akademia e Shkencave të Shqipërisë, Tiranë.

8. Fadil, S., (1984). Praktikumi i gjuhës shqipe, Enti i teksteve dhe i mjeteve mësimore I Kosovës, Prishtinë.

9. Gjovalin, Sh., (2006). Kultura e gjuhës, Shtëpia botuese e Librit universitar, Tiranë.

10. Kostallari, A., Domi, M., Çabej E., Lafe, E., (1973). Drejtshkrimi i Gjuhës Shqipe, Akademia e Shkencave të RP të Shqipërisë, Instituti i gjuhësisë dhe Ltërsisë, Tiranë.

11. Topalli, K., (2011). Bazat e gramatikës historike të gjuhës shqipe, Shtëpia botuese e Librit universitar, Tiranë.

12. Miklosich, F. (1856). Die Sprache der bulgaren in Sierbenburgen, Denkschriften der Wiener Akademie der Wissenschaften, Phil.-hist., kl., Bd. VII, Viena.

13. Buchholz, O. (1968). Zur frage der Verdoppelten der Objekte im albanischen, Aktes du I-Congres International des Etudes Balkaniques et Sud-Est Eropeennes, Sofia. 